\title{
Anticipating the Flood. Community-based cartography for disaster flood events in Argentina.
}

Ignacio Agustin Gatti a e *, Federico Ariel Robledo ${ }^{\text {b c d }}$, Sol Hurtado ${ }^{\text {b i }}$, Julieta Canneva ${ }^{\text {b i }}$, Diego

Moreira ${ }^{\mathrm{b} c \mathrm{~d}}$, Mariano Re ${ }^{\mathrm{fg}}$, Elodie Briche ${ }^{\mathrm{h}}$, Magdalena Falco ${ }^{\mathrm{bcd}}$, Leandro David Kazimierski ${ }^{\text {fg }}$ Ana Paula Micou ${ }^{\mathrm{j}}$

a Department of Natural Environmental Studies, Graduate School of Frontier Sciences, The University of Tokyo, Japan. gatti@csis.u-tokyo.ac.jp

b Department of Atmospheric and Ocean Sciences, School of Natural Sciences, University of Buenos Aires, Argentina.

$c$ Institut French-Argentine about Climate Studies and their Impacts, School of Natural Sciences, University of Buenos Aires \& Centre National de la Recherche Scientifique, France.

$d$ Research Center of the Sea and Atmosphere, Council of Technical and Scientific Research, Secretary of Government of Science,

Technology and Productive Innovation, Argentina.

e Natural Resources Research Program, Faculty of Philosophy and Letters, University of Buenos Aires, Argentina.

f National Water Institute, Argentina.

$g$ Department of Hydraulic, Faculty of Engineering, University of Buenos Aires, Argentina.

$h$ TEC CONSEIL, France.

i Research Group about South American Economic Development, High Social Studies Institute, University of San Martín, Argentina.

j National Geographic Institute, Argentina.

* Corresponding author

\begin{abstract}
:
"Anticipando la Crecida" Project (Anticipating the Flood) is an interdisciplinary project which deals with flood risk management strategies associated with intense rain events and southeasterly wind « sudestadas » in socio-economical vulnerable urban areas in Argentina. The objective of the current study is to use local knowledge through participatory activities to strengthen the phase of risk awareness of an early warning system by using cartography as a work tool. For this purpose, eleven workshops with adults and children were held between 2014 and 2017 in Buenos Aires metropolitan area and the towns of San Antonio de Areco and Santa Lucía.

By helping communities articulate and communicate spatial knowledge through workshops, enable the possibility to advocate for a change. That change result in a new direction on how the community and stakeholders can act towards a flood event. Analysing community-based maps of 85 adults, flood theoretical models can be evaluated and perhaps improved. Additionally, overall 287 students between 10 and 17 years old learned about cartography and interacted with poster maps during the workshops held in different schools.
\end{abstract}

Keywords: community-based maps; flood risk; workshops.

\section{Introduction}

Mapping is a pedagogical and planning tool that has the potential to conceptualize, create and use different sources to analyse simple and complex situations (Corbett and Lydon, 2016). As decision makers review programs and allocate resources, maps can be effective tools to stimulate discussion of current efforts and evaluate progress against goals (Measure Evaluation, 2014). Community-based maps are methodological resources used to help members of the communities to show how they "feel" and how they "see" their territories. It also collaborates with scientific research by gathering new information for validation and calibration of maps and theoretical models.
In flood prevention and preparedness, maps can be useful tools to build a sense of personal responsibility among citizens and also to empower communities towards informed decision-making as part of an overall flood risk management strategy (Minano and Peddle, 2018). Stakeholders informing their communities about flood risk and supporting flood management discussions are crucial actions for neighbourhoods which are exposed to flood events (CIRIA, 2015). Residents empowerment can result in an improvement of their spaces (Warner, 2015) and, eventually, lead to enhanced disaster risk strategies.

Children also can play an important role. Myridis et al (2007) states that a map can constitute an important communication tool for the first contact of a child with the 
environment. It correlate the territorial unit with the real area where they develop their everyday activities.

“Anticipando la Crecida” Project (Anticipating the Flood) is an interdisciplinary group composed of universities and institutions from Argentina. The Project deals with recurrent floods in different urban areas of the country. There have been three types of processes developed by Anticipando La Crecida in the last 5 years: (1) Doing fieldwork during flood events with local stakeholders (Civil Defense) to get water level measurements, monitoring the evolution of the water extension and evaluating the impact of the flood (2) Making the acquisition, installation and setting up of manual and automatic meteorological and hydrological equipment for some local Civil Defense buildings and particular stakeholders like schools and civil organizations. (3) Conducting workshops with the local community of all ages in order to learn about inhabitants' point of view of flood extent.

The objective of the current study is associated with the last type of activity (3). By using cartography as a key tool, it is possible to use local knowledge through participatory activities to strengthen the phase of awareness of the risk of an Early Warning System (EWS). The aim is to achieve the improvement of flood risk management strategies associated with intense rain events, streams overflow and southeasterly wind ${ }^{1}$ in socio-economical vulnerable populated areas.

Most of the cases are within Buenos Aires Metropolitan Area in the following neighbourhoods ${ }^{2}$ : Saavedra (City of Buenos Aires), La Ribera (Quilmes), Piñeiro (Avellaneda), Laferrere and Ciudad Evita (La Matanza), and Nueva Esperanza (Lomas de Zamora) (Figure 1). Additionally, another one was held in San Antonio de Areco city. It is only 100 kilometres away from the Buenos Aires Metropolitan Area and it is a distinguished area of large soybean and corn farmers. Moreover, a workshop was held in Santa Lucia (Corrientes Province) full of small farmers who produce tomatoes and peppers. All places are associated with lowland plain type of terrain. The locations in study have many streams inside or within the cities limits which frequently overflows and cause severe damage to the local population (Figure 2).

\footnotetext{
${ }^{1}$ Locally called "sudestadas" in Spanish. This kind of wind, when is strong and persistent, trigger floods on coastal areas of Buenos Aires city and surroundings. That type of flood typically last from a few hours to two or three days (Barros et al, 2007). La Ribera case is frequently inundated due to this group of wind.
}

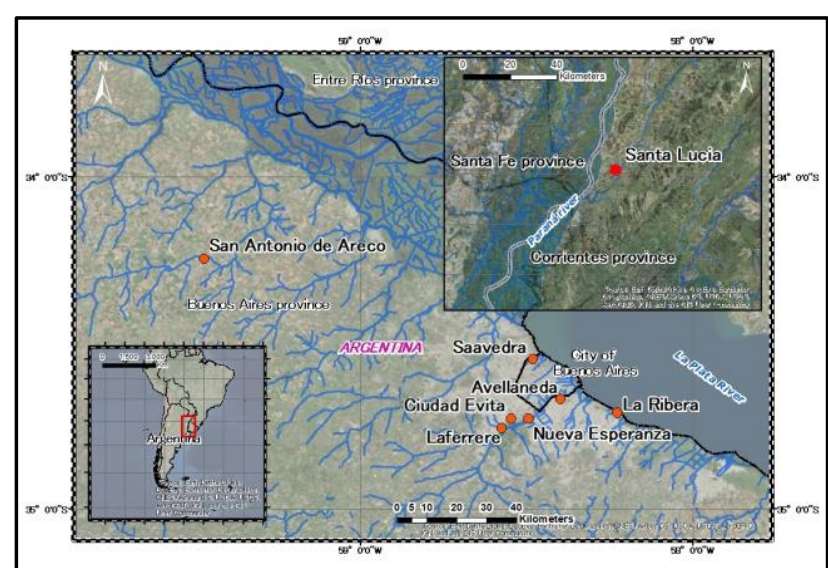

Figure 1. Location of case studies in Argentina.

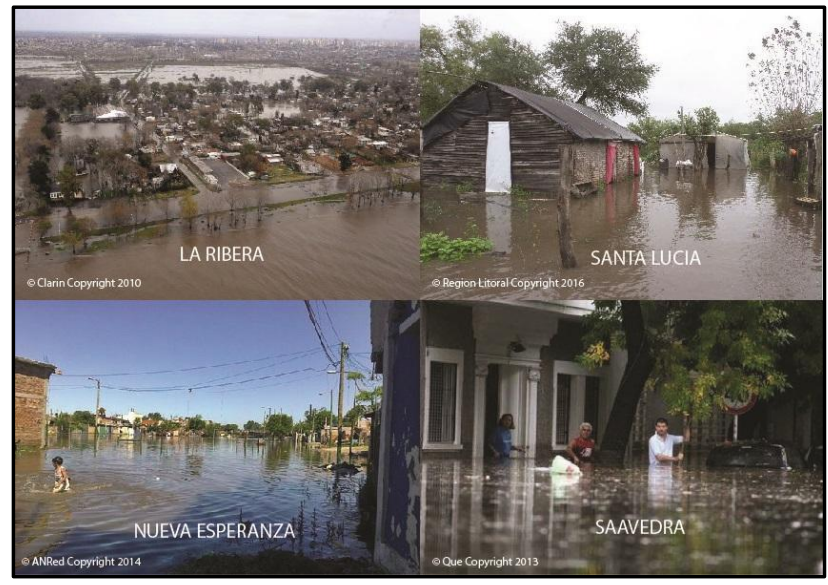

Figure 2. Flood events of urban areas in Argentina.

\section{Data and Methods}

\subsection{Data acquisition}

To interpret local population knowledge about flood events, the methodology consisted on organizing workshops using printed poster maps (at least 80-120 cm big) which were made with high-resolution aerial photographs from the National Geographic Institute (IGN) of Argentina ${ }^{3}$.

A Vexcel UltraCam Xp instrument was used to obtain 0,25 meters of spatial resolution aerial photos. This camera covered most of the areas selected except San Antonio de Areco and Santa Lucia. For those places, free 0.5 meters of spatial resolution imagery from Digital Globe satellite was used, available as an ARCGIS basemap. A projected coordinate system (POSGAR 2007 - Argentinian Geodesic Positions 2007) was adopted for all areas.

\footnotetext{
${ }^{2}$ The Districts are indicated in brackets.

${ }^{3}$ http://www.ign.gob.ar/
} 


\subsection{Workshops}

Anticipating the Flood activities included 11 workshops between 2014 and 2017 whose main objective was to obtain local knowledge of the flood hazard impact on the area (Table 1). Children workshops were held in different schools usually not far from the streams which frequently overflows. On the other hand, workshops with adult neighbours were organised in local governmental buildings like Social Development local institutions, Civil Defense or local community houses.

\begin{tabular}{|c|c|c|}
\hline Place & Date & Participants \\
\hline $\begin{array}{c}\text { School N.76, La } \\
\text { Ribera, Quilmes } \\
\text { district, Buenos Aires } \\
\text { province } \\
\text { (-34042'40'”; } \\
-58013 \text { '29') }\end{array}$ & $24 / 09 / 2014$ & $\begin{array}{c}41 \text { students } \\
\text { between } 14 \text { and } 17 \\
\text { years old. }\end{array}$ \\
\hline $\begin{array}{l}\text { School N.28, School } \\
\text { N.130 and School } \\
\text { N.135, } \\
\text { Laferrere, La Matanza } \\
\text { district, Buenos Aires } \\
\text { province } \\
\text { (-34044'59', } \\
\text {-58035'04',) }\end{array}$ & $\begin{array}{c}01 / 07 / 2015 \\
13 / 10 / 2015 \\
\text { and } \\
07 / 11 / 2016\end{array}$ & $\begin{array}{c}88 \text { students } \\
\text { between } 15 \text { and } 17 \\
\text { years old. }\end{array}$ \\
\hline $\begin{array}{l}\text { Social Development } \\
\text { building, Nueva } \\
\text { Esperanza, Lomas de } \\
\text { Zamora district, } \\
\text { Buenos Aires province } \\
\text { (-34043'43',; } \\
\text {-58029'38',) }\end{array}$ & $\begin{array}{c}24 / 04 / 2015 \\
\text { and } \\
15 / 05 / 2015\end{array}$ & $\begin{array}{c}42 \text { adults } \\
\text { between } 18 \text { and } 60 \\
\text { years old. }\end{array}$ \\
\hline $\begin{array}{l}\text { Community library, } \\
\text { Saavedra, City of } \\
\text { Buenos Aires } \\
\left(-34033^{\prime} 02^{\prime}, ;\right. \\
\left.-58028^{\prime} 47^{\prime} '\right)\end{array}$ & $15 / 08 / 2015$ & $\begin{array}{l}28 \text { adults between } \\
25 \text { and } 70 \text { years old. }\end{array}$ \\
\hline $\begin{array}{l}\text { Civil Defense } \\
\text { building, Santa Lucia, } \\
\text { Corrientes province } \\
\left(-28059^{\prime} 07^{\prime},\right. \\
-59006 \text { '03') }\end{array}$ & $18 / 07 / 2016$ & $\begin{array}{l}15 \text { adults between } \\
25 \text { and } 50 \text { years old. }\end{array}$ \\
\hline $\begin{array}{l}\text { School N.53, Piñeiro, } \\
\text { Avellaneda district, } \\
\text { Buenos Aires province } \\
\text { (-34040'18',; } \\
\text {-58023'16") }\end{array}$ & 06/08/2017 & $\begin{array}{l}25 \text { students between } \\
13 \text { and } 15 \text { years old. }\end{array}$ \\
\hline $\begin{array}{c}\text { School N.1, San } \\
\text { Antonio Areco City, } \\
\text { San Antonio Areco } \\
\text { district, Buenos Aires }\end{array}$ & $29 / 09 / 2017$ & $\begin{array}{l}78 \text { students between } \\
10 \text { and } 12 \text { years old. }\end{array}$ \\
\hline
\end{tabular}

\begin{tabular}{|c|c|c|}
\hline $\begin{array}{c}\text { province } \\
(-34014 ' 52 ', \\
-59028 ' 20 ')\end{array}$ & \\
\hline $\begin{array}{c}\text { School N.186, Ciudad } \\
\text { Evita, La Matanza } \\
\text { district, Buenos Aires } \\
\text { province } \\
\text { (-34043'10', }\end{array}$ & $23 / 11 / 2017$ & 13 students between \\
-58033'33'') & & 13 and 14 years old. \\
\hline
\end{tabular}

Table 1. Workshops with the local community held between 2014 and 2017.

\subsection{Activities with children}

Children workshops started with some icebreakers to introduce some basic cartography knowledge. Different activities were organised depending on the age of the participants. Questions were asked also in order to socialize with the students and make them to feel more comfortable. Workflows were separated in 5 steps:

\section{STEP 1 - INTRODUCTION OF CARTOGRAPHY \\ 1) What is a map? \\ 2) What kind of map do you know? \\ 3) Why are they important? Which uses do you know?
4) What is a scale? What scale can you see on this map?

The objective was to make the students understand the purpose of a map, the differences between cartography and reality. Once the interaction between the students and the facilitators concluded, the principal activity initiated.

\section{STEP 2 - LOCAL MAP}

5) Do you recognize this area?

6) What elements can you recognize of this map?

They were supposed to recognise their territory. The idea was to have an approach about the space they were going to work with and the information included on printed maps like scale, north arrow, streets names and others.

\section{STEP 3 - SOCIAL AND STRATEGIC PLACES}

This step consisted on using thumbtacks to localize two kind of places: social and strategic places. The first one referred to sites where the students meet, play and socialize with other scholars. On the other hand, strategic places indicated buildings and institutions which were considered important for early warning and flood management. They used two different colors to distinguish between social and strategic places. 
In order to trigger student interest on the activity, they had to write the legend of the map. One volunteer received the information of the rest of the class and put it on the edge of the poster. To involve them more deeply was important so they could take the activity seriously.

\section{STEP 4 - HOME LOCALIZATION AND FLOOD ANALYSIS}

In addition, each student had to find their own house and then put a thumbtack on the printed map. Three different color were available for the thumbtack: green, yellow and red. The green one indicated houses which were never inundated; a yellow thumbtack illustrated houses which were sometimes inundated; the red one was associated with houses which were always inundated (even when small river overflowed or when a local and small rainfalls occurs). The exception was in San Antonio de Areco workshop were only two categories were created: flooded and not flooded. The decision was made based on the average lower age of the participants (10 - 12 years old). In addition, the city had only two major floods due to river overflow which occurred in the last 10 years (2009 and 2015) and the children were not aware of this.

\section{STEP 5 - MAP NAME}

As the real architects of maps were the children, they were told that the final activity was to select an appropriate name for the map they had created. Even if the activity was related to floods, the idea was that they should selected any name they wanted. That name should represented better the final product. Those maps then were left in the school.

\subsection{Activities with adults}

While the activities with children focus on driving simply cartography notions and kids point of view about their own house flood exposure, adult neighbours analysed their own territory adding detailed information about what happened with frequent floods in a wider area. Once again, base maps were printed in poster version with high definition imagery already mention in 2.1. Some references on the map like streets and streams names, north arrow and scale were added in order give the community more tools to understand easily the cartographic product.

Workshops activities were divided into:

\section{STEP 1 - MAP INTRODUCTION}

An explanation about the source of the map, how was built and the objective of the activity was performed first.

\section{STEP 2 - NEIGHBOR HOUSE LOCATION}

In order to get more involved with the working space, they were supposed to find their own houses on the map. Spatial perception of their terrain could be different among population, so it was important to spend some time to take a look in detail the printed image.

\section{STEP 3 - FLOOD EXTENT ZONES}

To build flood extent zones based on local knowledge, two categories were created: normal/frequent floods and extraordinary floods/ sometimes flooded areas. Through discussing and sharing their vision of the hazard extent, the aim was to get a better understanding of their own space and the flood impact.

\section{STEP 4 - FLOOD MAIN CAUSES}

Answering the central questions of 'where' and 'what' is essential when dealing with challenges to flood main causes (Kienberg, 2014). Different driving forces were marked on the map by using community experience of past events.

\section{STEP 5 - STREAM OVERFLOW}

In the end, points where the nearest streams frequently overflow were identified and marked.

In order to characterize the flood hazard in the area and analyse the results obtained from the workshops, GIS (Geographical Information Systems) processes were performed using QGIS and ARCGIS.

\section{Results}

To ensure community participation and increase their resilience, geospatial concepts were discussed among academics, students and adults in the neighbourhoods.

Southeasterly wind continuously creates problems for the houses located near La Plata river coastline. For this reason the first workshop was held in the School N. 76 of La Ribera in 2014, less than 200 meters from the coast. The results showed that 7 children houses were always inundated, 17 houses were sometimes flooded and another 17 where the water level does not grow with meteorological storms so they are never flooded. Most of the inundated places were located in the center-east part of the neighbourhood (Figure 3). 


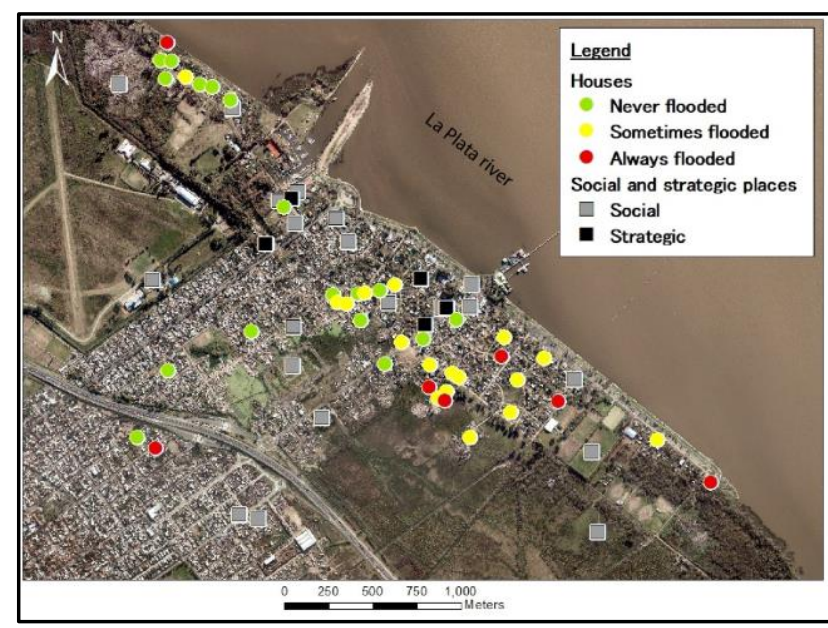

Figure 3. Children houses and social and strategic places in La Ribera, Quilmes.

In Laferrere workshops in three different schools were made in 2015 and 2016. We found that 17 houses were frequently inundated, 26 were sometimes flooded and 125 were never affected (Figure 4). It was detected that there were some houses occasionally flooded that were classified within a perimeter of a never inundated area. That showed that sometimes this kind of hazard event can be associated with very local flooded by a heavy rainfall above the area and not only to river overflow. Additionally, there were some students who possibly omitted part of the true of their house situation due to not be embarrassed or bullying by the rest of the group.

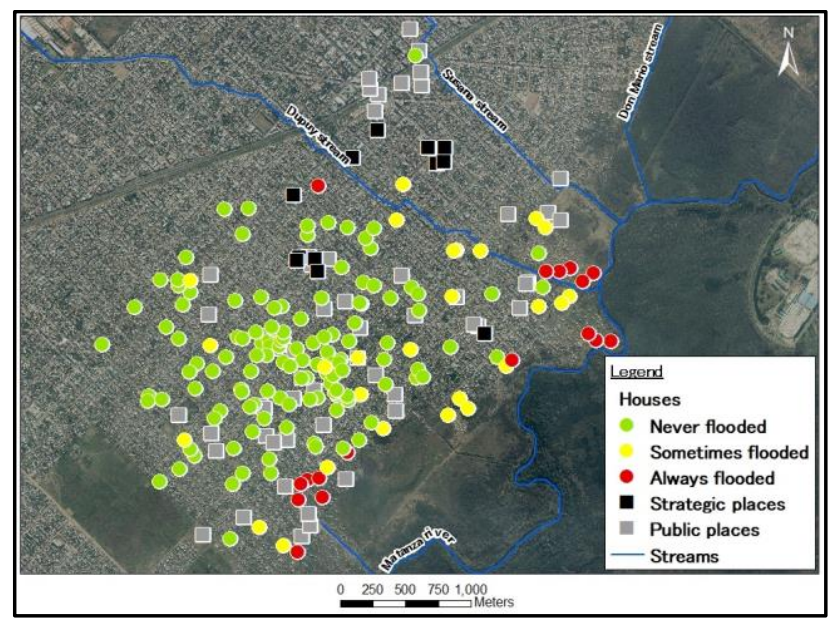

Figure 4. Laferrere workshops results.

Regarding the case of Nueva Esperanza, two workshops had place in April and May 2015 (Figure 5). This quarter is a squatter settlement created in 2001. Since its formation, experienced many flood events due to his location near the Matanza - Riachuelo river and one channel connected to it.

\footnotetext{
${ }^{4}$ In order to build more houses, some neighbours dismantled part of the levee that protected the quarter of the Matanza - Riachuelo river.
}

The main causes of flood events that neighbors pointed out were garbage and stone accumulation, a disappeared levee $^{4}$, two ditches which brought water to another part of the quarter, a fence for protection and general soil extraction.

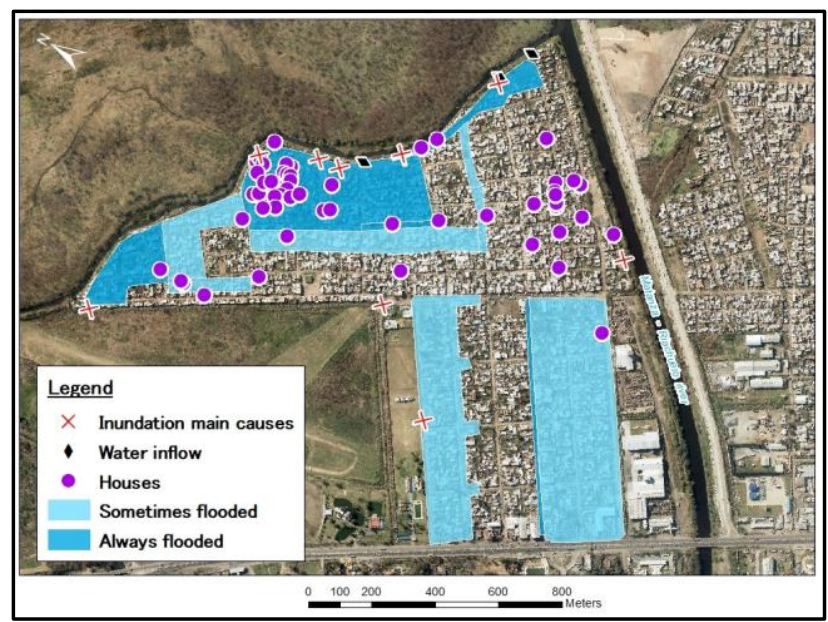

Figure 5. Results of Nueva Esperanza workshops.

After a big inundation happened in April 2013 when 6 people died, the local community of Saavedra started to be more active regarding the actions that City of Buenos Aires were taking to mitigate the problem. They created a webpage which publishes news, help to organise marches, broadcasts lectures and plan activities related to the issue 5 .

During the workshop set in 2015 (Figure 6 and 7), specifically after houses identification, two different areas were represented: always and sometimes flooded. Moreover, they pointed out on the map the main causes of flows like the construction of a shopping mall, a new fast bus line which slightly incremented the terrain topography, a railway line which creates a barrier, sinks shortage, pavement increased and others.

In addition, punctual areas where the nearest stream (Medrano) frequently overflows were marked on the map and written into the poster legend.

\footnotetext{
${ }^{5}$ http://www.asambleasaavedra.com.ar/
} 


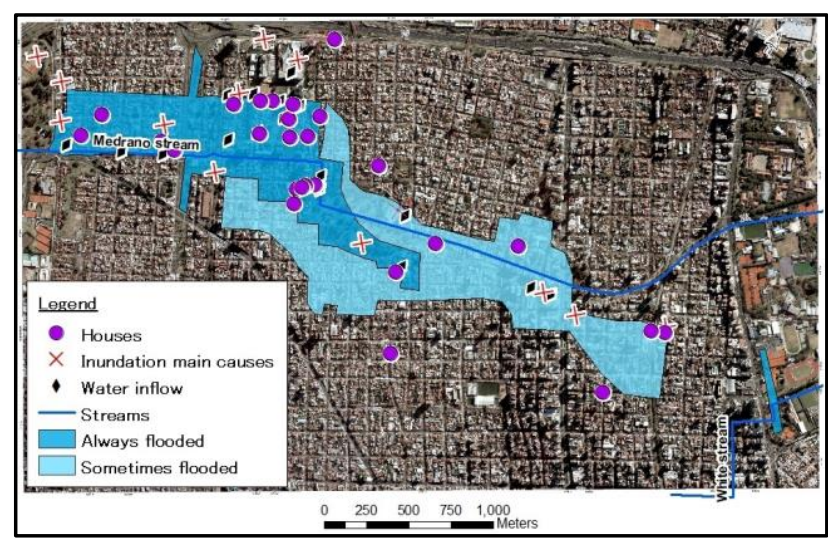

Figure 6. Saavedra workshop results.

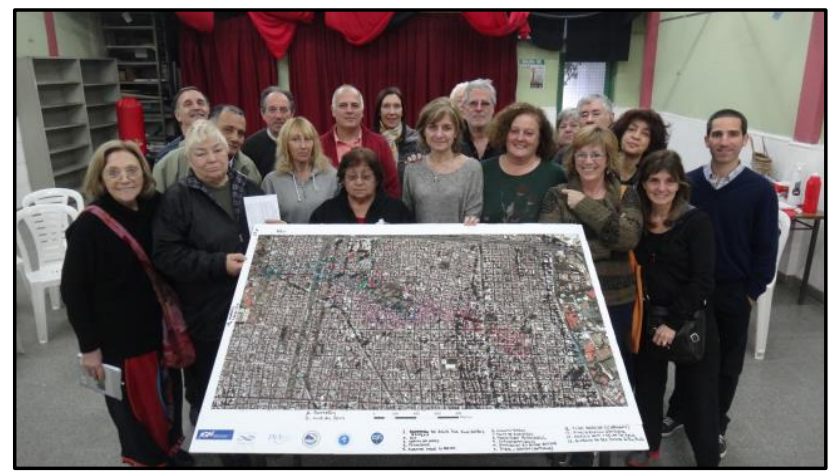

Figure 7. Saavedra workshop final product.

Just 3 months after a big flood of the Santa Lucia river, a workshop was held in the homonymous city in 2016 where 15 neighbours attended. Some of them had experienced also the flood of the year 1998 so they could compare both water levels (Figure 8). The participants included also a small area frequently inundated by local rainfall which is far from Santa Lucia river, where some neighbours had problems.

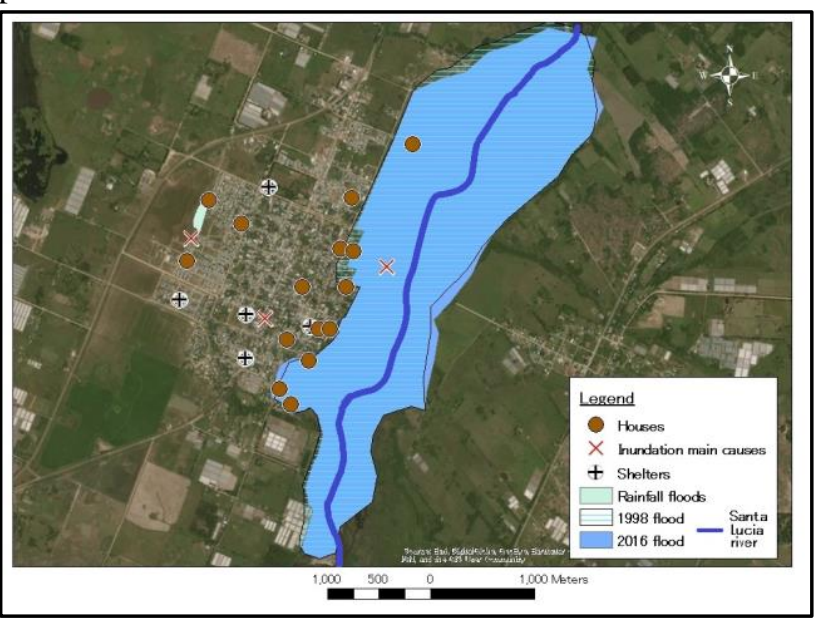

Figure 8. Mapping made by neighbors in Santa Lucia.

In Piñeiro (Avellaneda) in 2017 a workshop was organized in the School N. 53. In this zone, the Matanza - Riachuelo river discharges mainly over the south part of the urban area. As it is possible to interpret from the activity (Figure 9), 8 houses were always flooded, 10 houses were sometimes flooded and 7 have never had problems this problem.

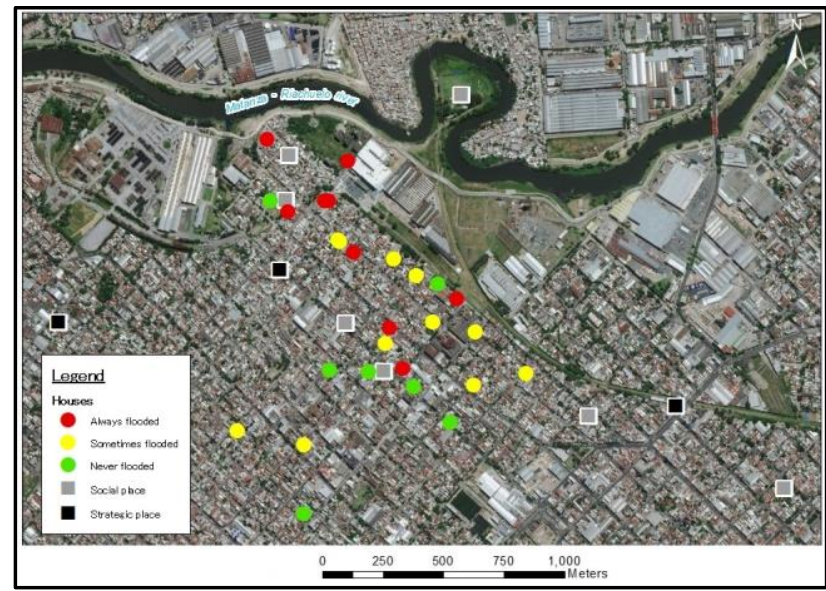

Figure 9. Distribution of the houses flooded and the social and strategic places during the workshop in Avellaneda in 2017.

One hundred kilometres away from Buenos Aires, a workshop was organized in the School N.1 in San Antonio de Areco city. Students identified 27 social places and 7 strategic places. In addition, they found that 12 of their houses were flooded in past event while 66 were safe (Figure 10 and 11). Among all inundated houses, one case was placed on the map far from the Areco river. That student had his house flooded by a very heavy rain which fell directly above the city and did not cause river overflow.

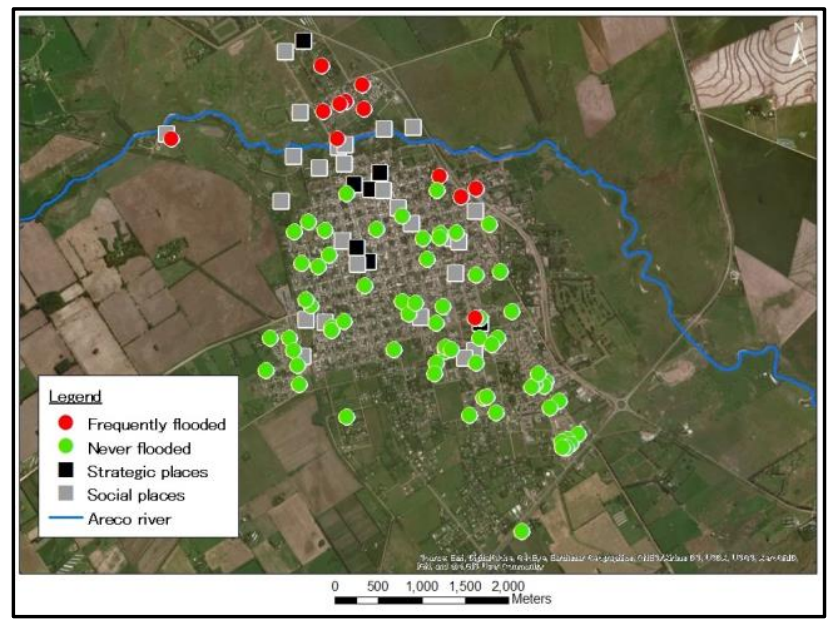

Figure 10. San Antonio de Areco city workshop results. 


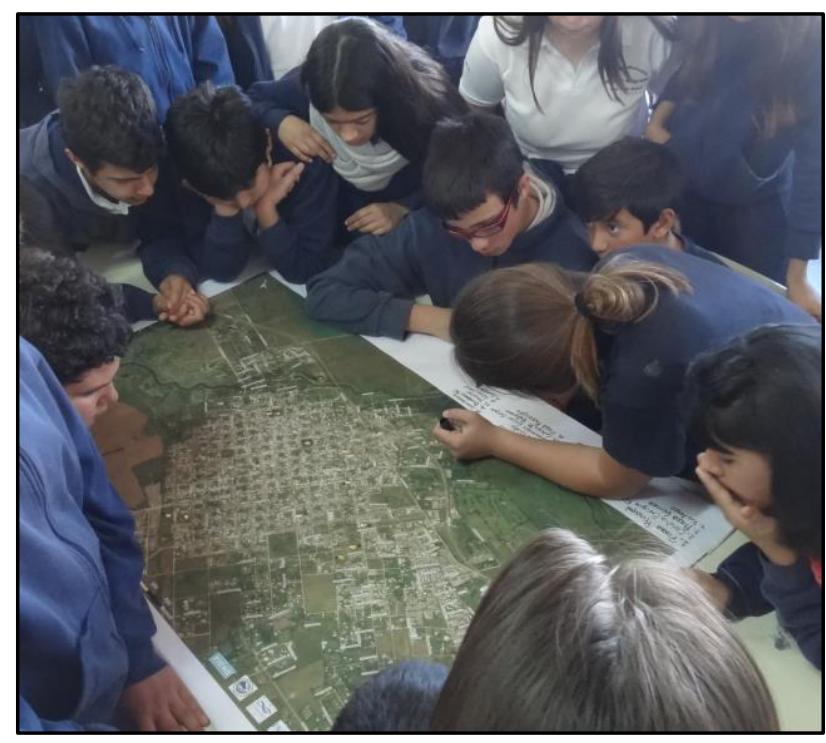

Figure 11. Students working with the map.

Finally, a small workshop was held in Ciudad Evita in the end of 2017. Some students had the possibility to state their vision of the quarter which had two small streams, one of them quite often causing inundation problems. Participants analysed the territory marking their social and strategic places as a first step. Secondly, they identified 6 houses always flooded, 3 that sometimes had flood problems and 4 that have not experienced any event (Figure 12).

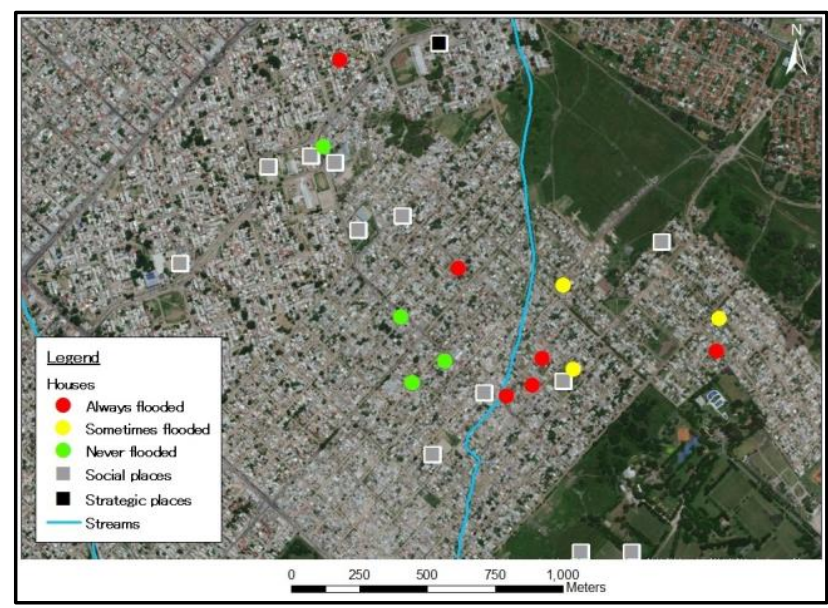

Figure 12. Results of the School N. 186 in Ciudad Evita.

\section{4.}

\section{Conclusions}

There is not one type of map which will work in every situation (Minano and Peddle, 2018). Analysing community-based cartographic products, flood theoretical models can be evaluated and perhaps improved. The visual impact of flood community-based maps is crucial because many times they reflect the real inundation situation in the neighbourhood. Eighty five adults shared their vision of

\footnotetext{
${ }^{6}$ The focus was on managing local early warning systems using
} official information from the National Weather Service (SMN).
Nueva Esperanza, Saavedra and Santa Lucía flooding situations.

Local knowledge about risk could also rethink the idea or the concept of rainfall thresholds that generate impact in the territory. Differences can be found among these and traditional statistical techniques for determining daily rainfall extremes. Anticipando La Crecida activities included a workshop with adults in Virrey del Pino (La Matanza district, Buenos Aires province) in November 2018 where thresholds were discussed and its results are currently being studied ${ }^{6}$.

Each person has a different mental map, a different sense of a place (Corbett and Lydon, 2016). By helping communities articulate and communicate spatial knowledge through workshops, enable the possibility to advocate for a change. That change result in a new direction on how the community and the stakeholders act towards floods.

Maps can be used effectively to support learning (Trumpower et al, 2014). Sometimes subjects like Geography or Cartography are not seriously studied during junior high school and high school. By combining an important problem for the community and introducing or reviewing cartographic language, the learning process could be very beneficial. Overall 287 students learned about cartography and used maps during the workshops. Among these, 106 student houses experimented flood problems.

The amount of perceived control that students have over their learning could be refer as empowerment (Jones et al. 2012). That empowerment should be directed to create valid and useful information for the stakeholders.

Cartography drive quick comprehension of hazard extension. Even if mapping alone cannot address any questions, embedding community-based approaches can help enhance community resilience (Osti, 2017). A spatial analysis of the situation can motivate the homeowners to act, to be more involved with local government decisions.

\section{5.}

\section{References}

Barros, V. et al (2007) “Cap III. Storm Surges, Rising Seas and Floods in Metropolitan Buenos Aires", in: Leary, N. et al (eds) Climate Change and Vulnerability and Adaptation: Two Volume Set., Earthscan, 1ed., 17p.

CIRIA (2015) Communication and engagement in local flood risk management, CIRIA, London, 74p. 
Corbett, J. and Lydon, M. (2016) A Community-based mapping: A tool for transformation, EBSCO Publishing, Cap. 5, pp.113-124.

Jones et al. (2012) "The Effects of Mind Mapping Activities on Students' Motivation”, International Journal for the Scholarship of Teaching and Learning, Vol. 6, No. 1, 22p. Available at: https://www.researchgate.net/publication/264889890_Th e_Effects_of_Mind_Mapping_Activities_on_Students $\% 2$ 7_Motivation

Kienberg, J. (2014) Participatory mapping of flood hazard risk in Munamicua, District of Búzi, Mozambique, Journal of Maps, 10:2, 269-275, DOI: 10.1080/17445647.2014.891265.

Measure Evaluation (2014) Mapping Community-Based Global Health Programs. A Reference Guide for Community-based Practitioners, Carolina Population Center, University of North Carolina at Chapel Hill, 38p

Minano, A. and Peddle, S. (2018) Using flood maps for community flood risk communication, Report prepared for Natural Resources Canada (NRCan-30006050733). Waterloo, Ontario, 22p.

Myridis et al (2007) "Cartography and Children. Designing a Multimedia Educational Tool.”, International Cartography Association, 23th International Cartographic Conference, 4-10 August 2007, Moscow, Russia, 13p. Available at: https://www.researchgate.net/publication/237051901_CA RTOGRAPHY_AND_CHILDREN_DESIGNING_A_M ULTIMEDIA_EDUCATIONAL_TOOL

Osti, R. (2017) "Embedding Community-Based Flood Risk Management in Investment. A part-to-wholeapproach", ADB East Asia Working Papers Series, Asian Development Bank, Manila, Philippines, 31 p.

Trumpower, D. L. (2014), Assessment for learning using digital knowledge maps. in: Digital Knowledge Maps in Education: Technology-Enhanced Support for Teachers and Learners. Springer New York, pp. 221-237. https://doi.org/10.1007/9781461431787_12

Warner, C. (2015) "Participatory Mapping: a literature review of community-based research and participatory planning", Spring 2015, 21p.

\section{$5.1 \quad$ Web pages:}

Agencia de Noticias RedAccion. 2014. [Online]. [12 February 2019]. Available from: https://www.anred.org/?p=43489

Anticipando la Crecida. 2019. [Online]. [14 February 2019]. Available from: http://anticipandolacrecida.cima.fcen.uba.ar/

Clarin. 2010. [Online]. [26 January 2019]. Available from: https://www.clarin.com/ciudades/CRECIDOCOSTANERA-QUILMES-ENSENADAEVACUADOS_CLAIMA20100814_0074_4.jpg

Que magazine. 2013. [Online]. [2 January 2019]. Available from:

https://www.revistaque.com/5/nota.php?nota_id=15386

Region Litoral. 2016. [Online]. [16 January 2019]. Available from:

https://www.regionlitoral.net/2016/04/corrientes-santalucia-bajo-agua.html

\section{Acknowledgements}

The project Anticipating the Flood is supported by "Exactas con la Sociedad", School of Natural Sciences, University of Buenos Aires. In addition we would like to thanks all the institutions who have participated from the beginning with the Project (2014) and supported all the workshops and fieldwork: National Weather Service, National Water Institute, National Geographic Institute, Research Center of the Sea and Atmosphere (Council of Technical and Scientific Research), University of San Martín, Institut French-Argentine about Climate Studies and their Impacts and Natural Resources Research Program (University of Buenos Aires). Finally we want to thank also to all local institutions, communities and schools where we had the workshops. 